\title{
PENGEMBANGAN DESAIN PEMBELAJARAN TEMATIK PADA TEMA INDAHNYA KEBERAGAMAN DI NEGERIKU BERBANTUAN LKS BUDAYA LOKAL BERORIENTASI MODEL PEMBELAJARAN KOOPERATIF JIGSAW UNTUK SISWA SEKOLAH DASAR
}

\author{
Ferdinandus Tando ${ }^{1}$, Dek Ngurah Laba Laksana ${ }^{2}$, Ermelinda Yosefa Awe ${ }^{3}$ \\ STKIP Citra Bakti \\ Malanuza. Jln Trans Ende-Bajawa-Nusa Tenggara Timur \\ Tandoferdinandus@gmail.com, labalaksana@citrabakti.ac.id, ermelindayosefaawe8@ gmail.com
}

\section{INFO ARTIKEL}

\section{Riwayat Artikel:}

Diterima: 18-Januari-2021

Disetujui: 30-Maret-2021

\section{Kata Kunci: \\ Desain pembelajaran tematik LKS budaya lokal Model pembelajaran kooperatif}

\section{ABSTRAK}

\begin{abstract}
Abstrak: Penelitian ini bertujuan untuk: 1) mengembangkan desain rencana pelaksanaan pembelajaran tematik pada tema Indahnya Keberagaman di Negeriku Berbantuan LKS Budaya Lokal Ngada Berorientasi Model Pembelajaran Kooperatif tipe Jigsaw untuk siswa SD. 2) Mengetahui kualitas produk hasil pengembangan desain rencana pelaksanaan pembelajaran tematik pada tema Indahnya Keberagaman di Negeriku Berbantuan LKS Budaya Lokal Ngada berorientasi model pembelajaran kooperatif tipe Jigsaw untuk siswa SD. Penelitian ini termasuk dalam penelitian pengembangan yang mengacu pada model pengembangan Dick and Carey. Metode yang digunakan dalam penelitian ini adalah berupa observasi, wawancara dan pencatatan dokumen. Sedangkan instrumen berupa angket yang berpatok pada Penilaian Badan Standarnisasi Nasional (BSN). Hasil penelitian ini adalah desain pembelajaran tematik pada tema Indahnya Keberagaman Di Negeriku Berbantuan LKS Budaya Lokal Ngada yang terdiri dari: Rencana pelaksanaan pembelajaran berbantuan lembar kerja siswa budaya lokal Ngada. Hasil kelayakan produk desain pembelajaran antara lain sebagai berikut: penilaian ahli materi memperoleh nilai rata-rata 97,57\% dengan kategori sangat layak, penilaian ahli desain pembelajaran memperoleh nilai rata-rata $81,82 \%$ dengan kategori layak dan penilaian ahli bahasa memperoleh nilai rata-rata 93,33\% dengan kategori sangat layak. Berdasarkan hasil data tersebut maka, desain pembelajaran tematik pada tema Indahnya Keberagaman di Negeriku Berbantuan LKS Budaya Lokal Ngada berorientasi model pembelajaran kooperatif tipe Jigsaw untuk siswa SD layak untuk digunakan.
\end{abstract}

\begin{abstract}
This study aims to: 1) develop a thematic learning implementation plan design with the theme the beauty of diversity in my country assisted worksheets of by Ngada culture oriented to the type of Jigsaw cooperative learning model for elementary school students. 2) Knowing the quality of the product as a result of the development of the thematic learning implementation plan on the theme of the beauty of diversity in my country with assisted worksheets of by Ngada culture oriented to the type of Jigsaw cooperative learning model for elementary school student. This research is included in development research which refers to the Dick and Carey development model. The method used in this research is observation, interview and document recording. While the instrument is in the form of a questionnaire which is based on the Assessment of the National Standardization Agency (BSN). The result of this research is a thematic learning design on the theme of the beauty of diversity in my country assisted with Ngada culture student worksheet which consists of: Learning implementation plan assisted by Ngada culture student worksheets. The results of the feasibility of learning design products include the following: the material expert's assessment obtained an average value of $97.57 \%$ with the very feasible category, the learning design expert's assessment obtained an average value of $81.82 \%$ with the feasible category and the linguist's assessment obtained an average score -Average 93.33\% with very feasible category. Based on the results of these data, the thematic learning design on the theme of the beauty of diversity in my country assisted by the Ngada culture students worksheets oriented to the Jigsaw type of cooperative learning model for elementary school students is feasible to use.
\end{abstract}




\section{A. LATAR BELAKANG}

Undang-undang Sisdiknas No. 20 tahun 2003 menyatakan bahwa pendidikan adalah usaha sadar dan terencana untuk mewujudkan suasana belajar dan proses pembelajaran agar peserta didik secara aktif mengembangkan potensi dirinya untuk memiliki kekuatan spritual keagamaan, pengendalian diri, kepribadian, kecerdasan, akhlak mulia serta keterampilan yang diperlukan dirinya, masyarakat, bangsa dan negara. Peningkatan mutu pendidikan formal di sekolah, tidak terlepas dari tuntutan keberhasilan proses kegiatan pembelajaran. Proses kegiatan pembelajaran tersebut dipengaruhi oleh beberapa komponen utama yang saling berkaitan satu sama lainnya, diantaranya adalah guru, siswa, metodedan perangkat pembelajaran. Komponen komponen tersebut memiliki peranan penting dalam menentukan keberhasilan proses kegiatan pembelajaran, sehingga akan mempengaruhi hasil belajar siswa. Namun pada prakteknya dilapangan, pembelajaran yang terjadi di Kabupaten Ngada lebih umumnya di wilayah NTT masih banyak mengedepankan fungsi guru sebagai nakhoda utama dan satu-satunya dalam kelas. Apalagi pada sekolah-sekolah yang berada di daerah pinggiran. Sarana dan prasarana yang tersedia sangat minim. Selain itu, kegiatan pembelajaran belum memanfaatkan teknologi informasi sebagai media pengantar sebagaimana diisyaratkan dalam Kurikulum 2013. Siswa yang bersekolah rata-rata berasal darikeluarga menengah ke bawah. Sehingga guru hanya memanfaatkan buku sebagai media dalam pembelajaran (Laksana, 2015). Untuk mencapai hasil yang maksimal, guru diharapkan dapat mengembangkan perangkat pembelajaran sehingga dapat meningkatkan hasil belajar siswa.

Seorang guru sangat berperan penting bagi peserta didik dalam proses belajar mengajar, maka guru harus memiliki kemapuaan atau kompetensi guru yang mengajar dan membimbing mereka. Salah satu faktor yang paling penting dalam proses belajar mengajar bagi seorang guru untuk memberikan pelajaran kepada siswa agar mereka benar-benar memahami yang diajarkan adalah mengenai sumber belajar atau bahan ajar yang diajarkan. Dalam proses belajar mengajar bahan yang paling sering digunakan oleh guru pada saat mengajar adalah buku. Buku merupakan bahan ajar yang di dalamnya terdapat ilmu yang masi bersifat umum sehingga guru haru menjelaskan secara rinci serta memberikan contoh agar siswa muda memahami. Sebagai seorang pendidik, guru harus benar-benar menguasai isi buku yang akan diajarkan, maka agar lebih muda menguasai buku yang menjadi bahan ajar, guru dapat mendesain dan mengembangkan bahan yang akan diajarkan.

Suatu pembelajaran yang tidak didesain secara sistematis tidak dapat memperoleh hasil yang maksimal. Sebaliknya keberhasilan pelaksanaan pembelajaran sangat bergantung pada sejau mana pembelajaran itu didesain atau direncanakan. Namun, tidak semua guru berkesempatan melakukannya, mungkin karena banyaknya pekerjaa sampingan yang dilakukan selain menjalankan tugas sebagai guru, mungkin juga tidak memilki pengetahuan yang memadai untuk mendesain pembelajaran secara sistematis, atau mungkin menganggap bahwa pembelajaran yang hendak dilakukan sudah dapat dikuasai sehingga merasa tidak perlu didesain atau direncanakan. Anggapan seperti itu telah berimbas pada kepercayaan diri sebagai guru untuk berani melaksanakan pembelajaran tampah bermodalkan rancangan, akibatnya pembelajaran cendrung dilaksanakan dengan metode lansung yang sering tidak terkontrol, baik dalam kaitanya dengan penggunaan waktu maupun pemberian materi. Dengan demikian berbicara tentang desain pembelajaran adalah sesuatu yang sangat penting dalam proses pembelajaran dengan adanya desain pembelajaran maka pembelajaran akan berjalan sesuai dengan waktu yang telah ditentukan dan selain itu juga pembelajaran dapat berjalan dengan baik dan efektif. Desain pembelajaran yang dimaksudkan disini adalah Rencana Pelaksanaan Pembelajaran (RPP).

Menurut Permedikbud Nomor 65 Tahun 2013 tentang standar proses menjelaskan bahwah Rencana Pelaksanaan Pembelajaran (RPP) merupakan suatu rencana kegiatan pembelajaran tatap muka untuk satu pertemuan ataupun lebih. RPP berkembang dari silabus untuk lebih mengarahkan kegiatan pembelajaran peserta didik untuk mencapai Kompetensi Dasar. Selain itu juga berbicara tentang RPP tidak dapat dipisakan dari seorang guru dengan adanya rencana pelakasnaan pembelajaran maka pembelajaran yang terjadi didalam kelasa akan terarah dan akan berjalan sesuai dengan yang telah dirancang sebelumnya.

Berdasarkan hasil pengamatan di Kabupaten Ngada, diketahui bahwa RPP yang digunakan masih bersumber dari RPP yang diperoleh dari website, bersumber dari buku yang diberikan dari pemerintah, dimana hal-hal yang tertera didalamnya masih belum mengutamakan sesuatu yang bersifat budaya atau sesuatu yang berkaitan dengan keadaan sekitar peserta didik atau budaya lokal sekitar peserta didik. Budaya local yang dimaksudkan adalah sesuatu yang ada di daerah sekitar Kabupaten Ngada bukan sesuatu yang diluarnya, sehingga dalam proses pembelajaran siswa merasa jenuh dan kurang antusias dalam melaksanakan kegiatan belajar mengajar, selain itu juga hasil belajar peserta didik yang di peroleh tidak sesuai dengan apa yang di inginkan dan direncanakan. Peningkatan hasil belajar peserta didik juga tidak terlepas dari tuntutan keberhasilan proses kegiatan pembelajaran. Proses kegiatan pembelajaran tersebut dipengaruhi oleh beberapa komponen utama yang saling berkaitan satu sama lainnya, diantaranya adalah guru, siswa dan metode pembelajaran.

Materi yang diajarkan pada kurikulum 2013 yaitu secara tematik. Pembelajaan tematik adalah pembelajaran terpadu yang menggunakan tema untuk mengaitkan beberapa mata pelajaran sehingga dapat 
memberikan pengalaman bermakna kepada siswa. Keterpaduan berdasarkan tema akan menghubungkan persoalan satu dengan persoalan lainnya, sehingga terbangunlah kesatuan (unity) pengetahuan. Sebuah pengetahuan yang mempresentasikan kesatuan bagian-bagian dengan keseluruhannya. Integrasi dalam pembelajaran diharapkan melahirkan pemahaman yang komprehensif pada diri peserta didik dan lingkungannya. Hal ini terkait dengan pemahaman bahwa diri manusia adalah bagian dunia yang lebih luas, sehingga peserta didik mampu memahami pengetahuan yang diterimanya melalui kurikulum beserta implementasi dan perkembangannya dalam kehidupan sehari-hari.

Salah satu upaya dalam meningkatkan kualitas pendidikan adalah dengan cara memperbaiki kualitas pembelajaran, dimana pendidik harus mampu memilih serta menerapkan model pembelajaran yang sesuai dengan karakteristik materi sehingga mampu membelajarkan peserta didik dalam mengkonstruksi pemahaman mengenai konsep dalam mengembangkan daya nalar secara optimal. Salah satu model pembelajaran yang digunakan guru yaitu model pembelajaran Kooperatif tipe Jigsaw. Menurut Huda (2011) model pembelajaran kooperatiftipe Jigsaw adalah suatu tipe pembelajaran kooperatif yang terdiri dari beberapa anggota dalam satu kelompok yang bertanggung jawab atas penguasaan bagian materi belajar dan mampu mengajarkan materi tersebut kepada anggota lain dalam kelompoknya. Model pembelajaran kooperatif tipe Jigsaw merupakan model pembelajaran kooperatif dimana siswa belajar dalam kelompok kecil yang terdiri dari 4-6 orang secara heterogen dan bekerja sama saling ketergantungan yang positif dan bertanggung jawab atas ketuntasan bagian materi pelajaran yang harus dipelajari dan menyampaikan materi tersebut kepada anggota kelompok yang lain. Penggunaan model pembelajaran kooperatif tipe Jigsaw sudah digunakan oleh banyak peneliti dalam kegiatan pembelajaran antara lain penelitian yang dilakukan oleh khoiruddin (2014) dengan judul Pengembangan Model Pembelajaran Kooperatif Tipe Jigsaw pada materi bilangan di kelas VII B MTs Nurul jadid sidayu, hasil penelitian menunjukan bahwa kevalidan RPP berkategori valid $(3,3)$, kevalidan buku siswa berkategori valid $(3,4)$, kevalidan LKS berkategori valid $(3,6)$, masing-masing perangkat pembelajaran dinilai praktis oleh para ahli, aktivitas siswa dapat dikatakan efektif (seluruh aspek telah memenuhi kriteria waktu efektif), keterlaksanaan sintaks pembelajaran memenuhi kriteria efektif (setiap pertemuan $>75 \%$ terlaksana dengan nilai 2,95), respon siswa terhadap proses pembelajaran adalah positif, dan hasil belajar siswa memenuhi batas ketuntasan secara individual dan klasikal (83,33\%). Oleh karena itu perlu dilakukan penelitian dan pengembangan desain perangkat pembelajaran tematik yang sesuai dengan model pembelajaran tipe Jigsaw, sehingga peneliti terdorong untuk mengadakan penelitian dengan judul "Pengembangan Desain Pembelajaran Tematik pada Tema Indahnya Keragaman di Negeriku Berbantuan LKS Budaya Lokal Ngada Berorientasi Model Pembelajaran Kooperatif Tipe Jigsaw untuk Siswa SD".

Berdasarkan latar belakang di atas, maka rumusan masalah yang diajukan dalam penelitian ini adalah sebagai berikut. 1) Apakah dapat dihasilkan produk pembelajaran tematik pada tema indahnya keberagaman di negeriku berbantuan LKS budaya lokal Ngada berorientasi model pembelajaran kooperatif tipe Jigsaw untuk siswa SD? 2) Bagaimanakah kualitas produk hasil pengembangan desain pembelajaran tematik pada tema indahnya keberagaman di negeriku berbantuan LKS budaya lokal ngada berorientasi model pembelajaran kooperatif tipe Jigsaw untuk siswa SD?

Produk yang dihasilkan berupa rencana pelaksanaan pembelajaran (RPP) tematik pada tema indahnya keberagaman di negeriku berbantuan LKS budaya lokal Ngada berorientasi model pembelajaran kooperatif tipe Jigsaw.

\section{B. METODE PENELITIAN}

Jenis penelitian yang akan dilakukan dalam penelitian ini adalah penelitian pengembangan. Metode pengumpulan dan pengembangan yang digunakan dalam penelitian ini adalah sebagai berikut. 1) metode angket 2) metode dokumentasi sedangkan instrumen dalam penelitian pengembangan desain pembelajaran ini adalah berupa angket dan dokumentasi. Data mengenai kualitas desain pembelajaran tematik berbasis pembelajaran kooperatif tipe Jigsaw dengan suplemen lembar kerja siswa berbasis budaya lokal Ngada, hasil review ahli dianalisis secara deskriptif untuk mengolah data hasil review ahli materi, ahli desain pembelajaran, ahli bahasa. Teknik analisis data ini dilakukan dengan mengelompokan informasi dari data kualitatif yang berupa masukan, tanggapan, kritik, dan saran perbaikan yang terdapat pada angket. Hasil analisis ini kemudian digunakan untuk merevisi produk yang dikembangkan.

\section{HASIL DAN PEMBAHASAN \\ Hasil Penelitian}

\section{Desain awal produk}

Kegiatan pengembangan ini menghasilkan produk berupa desain pembelajaran tematik pada tema indahnya keberagaman dinegeriku berbantuan LKS budaya lokal Ngada berorientasi medel pembelajaran kooperatif tipe 
Jigsaw untuk siswa kelas IV SDK Nunupada Kecamatan Inerie Kabupaten Ngada. Adapun deskripsi hasil penelitian dan pengembangan yang dilakukan menggunakan model Dick and Carey. Model pengembangan Dick and Carey yang dimodifikasi ini menggunakan 10 tahap, yaitu, 1) Mengidentifikasi tujuan umum pembelajaran, 2) Melaksanakan analisis pembelajaran, 3) Mengidentifikasi tingkah laku masukan dan karakteristik siswa, 4) Merumuskan tujuan performansi, 5) Mengembangkan instrumen penilaian, 6) Mengembangkan strategi pembelajaran, 7) Mengembangkan dan memilih materi pembelajaran, 8) Melaksanakan dan memilih evaluasi formatif, (9) Merevisi bahan pembelajaran, 10) Merancang/mendesain dan evaluasi sumatif. Berikut penjelasan tahapan-tahapan dalam penelitian pengembangan desain pembelajaran tematik berbasis pembelajaran kooperatif tipe Jigsaw pada tema indahnya keragaman di negeriku dengan suplemen lembar kerja siswa berbasis budaya lokal Ngada.

a) Mengidentifikasi Tujuan Umum Pembelajaran:

Tujuan umum pembelajaran untuk setiap tema dan sub tema (kompetensi dasar) dalam desain pembelajaran tematik pada tema indahnya keberagaman dinegeriku berbantuan LKS budaya lokal Ngada berorientasi model pembelajaran kooperatif tipe Jigsaw dapat dijabarkan sebagai berikut. 1) Pada sub tema 1. Tujuan umum pembelajaran pada sub tema 1 terdiri dari 5 mata pelajaran antara lain sebagai berikut. (1) Bahasa Indonesia. Kompetensi dasar mata pelajaran Bahasa Indonesia pada sub tema 1 adalah KD: 3.7 Menggali pengetahuan baru yang terdapat dalam teks nonfiksi dan KD 4.7 Menyampaikan pengetahuan baru dari teks nonfiksi ke dalam tulisan dengan bahasa sendiri. (2) Ilmu Pengetahuan Alam. Kompetensi dasar mata pelajaran Ilmu Pengetahuan Alam pada sub tema 1 adalah KD: 3.3 Mengidentifikasi macam-macam gaya, antara lain: gaya otot, gaya listrik, gaya magnet, gaya grafitasi, dan gaya gesekan dan KD 4.3 Mendemonstrasikan manfaat gaya dalam kehidupan sehari-hari, misalnya gaya otot, gaya listrik, gaya magnet, gaya grafitasi, dan gaya gesekan. (3) Ilmu Pengetahuan Sosial. Kompetensi dasar mata pelajaran Ilmu Pengetahuan Sosial pada sub tema 1 adalah KD: 3.2 Mengidentifikasi keragaman sosial, ekonomi, budaya, etnis, dan agama di provinsi setempat sebagai identitas bangsa Indonesia serta hubungannya dengan karakteristik ruang dan KD 4.2 Menyajikan hasil identifikasi mengenai keragaman sosial, ekonomi, budaya, etnis, dan agama di provinsi setempat sebagai identitas bangsa Memahami pentingnya upaya keseimbangan dan pelestarian sumber daya alam di lingkungannya. (4) SBdP. Kompetensi dasar mata pelajaran SBdP pada sub tema 1 adalah KD 4.2 Menyanyikan lagu dengan memperhatikan tempo dan KD 4.4 Mengetahui tanda tempo dan tinggi rendah nada. (5) PPKn. Kompetensi dasar mata pelajaran PPKn pada sub tema 1 adalah KD 3.4 Mengidentifikasi berbagai bentuk keragaman suku bangsa, sosial, dan budaya di Indonesia yang terikat persatuan dan kesatuan dan KD 4.2 Menyajikan berbagai bentuk keragaman suku bangsa, sosial, dan budaya di Indonesia yang terikat persatuan dan kesatuan. 2) Pada sub tema 2. Tujuan umum pembelajaran pada sub tema II terdiri dari 5 mata pelajaran antara lain sebagai berikut. (1) Bahasa Indonesia. Kompetensi dasar mata pelajaran Bahasa Indonesia pada sub tema 2 adalah KD: 3.7 Menggali pengetahuan baru yang terdapat dalam teks nonfiksi dan KD 4.7 Menyampaikan pengetahuan baru dari teks nonfiksi ke dalam tulisan dengan bahasa sendiri. (2) Ilmu Pengetahuan Alam. Kompetensi dasar mata pelajaran Ilmu Pengetahuan Alam pada sub tema 2 adalah KD: 3.3 Mengidentifikasi macam-macam gaya, antara lain: gaya otot, gaya listrik, gaya magnet, gaya grafitasi, dan gaya gesekan dan KD 4.3 Mendemonstrasikan manfaat gaya dalam kehidupan sehari-hari, misalnya gaya otot, gaya listrik, gaya magnet, gaya grafitasi, dan gaya gesekan. (3) Ilmu Pengetahuan Sosial. Kompetensi dasar mata pelajaran Ilmu Pengetahuan Sosial pada sub tema 2 adalah KD: 3.2 Mengidentifikasi keragaman sosial, ekonomi, budaya, etnis, dan agama di provinsi setempat sebagai identitas bangsa Indonesia serta hubungannya dengan karakteristik ruang dan KD 4.2 Menyajikan hasil identifikasi mengenai keragaman sosial, ekonomi, budaya, etnis, dan agama di provinsi setempat sebagai identitas bangsa Memahami pentingnya upaya keseimbangan dan pelestarian sumber daya alam di lingkungannya. (4) SBdP. Kompetensi dasar mata pelajaran SBdP pada sub tema 2 adalah KD 3.3 Mengetahui gerak tari kreasi daerah. KD 4.3 Meperagakan gerak tari kreasi daerah. (5) PPKn. Kompetensi dasar mata pelajaran PPKn pada sub tema 2 adalah KD 3.4 Mengidentifikasi berbagai bentuk keragaman suku bangsa, sosial, dan budaya di Indonesia yang terikat persatuan dan kesatuan dan KD 4.2 Menyajikan berbagai bentuk keragaman suku bangsa, sosial, dan budaya di Indonesia yang terikat persatuan dan kesatuan.

b) Analisis Pembelajaran atau Analisis Instruksional:

Dari analisis standar kompetensi anak selanjudnya dilakukan analisis pembelajaran untuk mengetahui keterampilan yang harus dikuasai oleh siswa. Keterampilan yang dimaksud adalah kompetensi dasar yang hendak dikembangkan pada desain perangkat pembelajaran tematik pada tema indahnya keberagaman dinegeriku berbantuan LKS budaya lokal Ngada berorientasi medel pembelajaran kooperatif tipe Jigsaw.

Pada tahap analisis pembelajaran ini menghasilkan rencana pelaksanaan pembelajaran yang sesuai dengan kurikulum yang ada dan berpatok pada standar kompetensi yang dikembangkan berorientasi model 
pembelajaran kooperatif tipe Jigsaw pada tema indahnya keragaman di negeriku berbantuan lembar kerja siswa budaya lokal Ngada.

c) Mengidentifikasi Karakteristik Peserta Didik:

Pada tahap ini, peneliti melakukan analisi karakteristik anak di SDK Nunupada. Hasilnya adalah sebagai berikut. 1) Anak yang berada di kelas IV adalah peserta didik yang cukup cepat tanggap. 2) Anak kelas IV di SDK Nunupada terdiri dari 21 orang anak. 3) Kemampuan aktual peserta didik di kelas ini terbilang sukup tnggi, merekan cukup cepat menangkap pembelajaran yang diberikan oleh pendidik.

d) Merumuskan Tujuan Pembelajaran Khusus:

Tujuan pembelajaran khusus untuk setiap tema dan sub tema dalam desain pembelajaran tematik pada tema indahnya keberagaman dinegeriku berbantuan lks budaya lokal ngada berorientasi model pembelajaran kooperatif tipe jigsaw dapat dijabarkan sebagai berikut. 1) Sub tema I. Tujuan pembelajaran khusus pada sub tema 1 terdiri dari 5 mata pelajaran antara lain sebagai berikut. (1) Bahasa Indonesia. Menyebutkan isi informasi baru dari teks nonfiksi "Suku dan Adat Istiadat di Kabupaten Ngada: Menyebutkan informasi tentang pokok pikiran setiap paragraf dalam bacaan. Menemukan kata sulit yang terdapat dalam teks bacaan. Menuliskan arti kata sulit yang ditemukan dengan bahasa sendiri. (2) Ilmu Pengetahuan Alam. Menjelaskan pengertian gaya secara umum. Menjelasan pengertian gaya otot dan pengaruhnya terhadap benda. Mendemonstrasikan manfaat gaya otot dalam kehidupan sehari-hari. (3) Ilmu Pengetahuan Sosial. Mengenal suku bangsa yang ada di Ngada dengan benar. Mengenal keadaan pulau-pulau di Ngada dengan benar. Memahami faktor penyebab keragaman di Kabupaten Ngada. Menyebutkan kegiatan yang akan menyebabkan punahnya behasa daerah. (4) SBdP. Menjelaskan pengertian tempo. Menyebutkan 3 macam tempo. Mengidentifikasi tempo pada teks lagu "Bengu Rele Kaju". Menyanyikan lagu "Bengu Rele Kaju" sesuai tempo. (5) PPKn. Menjelaskan arti penting toleransi Menjelaskan sikap toleransi yang dapat diterapkan di lingkungan sekolah. Menyebutkan perlunya bersikap toleransi dalam kehidupan sehari-hari. Memahami faktor penyebab keragaman di Kabupaten Ngada. Menyebutkan kegiatan yang akan menyebabkan punahnya behasa daerah. 2) Sub tema II. (1) Bahasa Indonesia. Menyebutkan informasi baru tentang Ghami Ata Riung, Suku Ngada dengan tepat. Menyebutkan kata-kata sulit dan menuliskan gagasan pokok setiap paragraf dalam teks dengan benar. Menemukan informasi baru dengan benar. (2) Ilmu Pengetahuan Alam. Menjelaskan manfaat gaya listrik dengan benar. Menuliskan pengetahuan baru tentang listrik statis dan listrik dinamis dengan rinci. Membedakan pengertian listrik statis dan listrik dinamis dengan bahasa sendiri secara tepat. Menjelaskan penyebab alat-alat elektronik dapat digunakan sesuai fungsinya dengan tepat. (3) Ilmu Pengetahuan Sosial. Menceritakan daerah asal dan keunikan dari setiap rumah adat dengan tepat. (4) SBdP. Menjelaskan pola lantai dengan benar. Memperagakan pola lantai gerakan tarian daerah yang diamatinya dengan percaya diri. (5) PPKn. Menjelaskan tentang bentuk, bahan pembuat, dan keunikan dari rumah adat daerah mereka dengan tepat

e) Mengembangkan Instrumen Penilaian:

Untuk mengetahui kelayakan produk, maka peneliti perlu dikembangkan sebuah intrumen penilaian. Adapun instrumen penilaian yang dikembangkan adalah instumen penilaian ahli materi, ahli bahasa dan ahli desain pembelajaran. Pada tahap ini peneliti mulai mengembangkan instrumen penilaian desain pembelajaran tematik pada tema indahnya keberagaman dinegeriku berbantuan LKS budaya lokal Ngada berorientasi model pembelajaran kooperatif tipe jigsaw. Dalam pengembangan produk, untuk mengetahui dan menentukan kesimpulan yang telah dicapai maka ditetakpan kriteria sesuai tingkat validitas. Adapun spesifikasi instrumen penilaian tersebut adalah: 1) Instrumen yang dibuat adalah instrumen penilaian ahli materi, intrumen penilaian ahli bahasa dan instrumen penilaian ahli desain. 2) Instrumen penilaian ini juga dilengkapi dengan rubrik penilaian yang menggunakan skala 1 hingga 5. 3) Materi yang dipilih untuk menampilkan aspek desain pembelajaran tematik berbantuan LKS budaya lokal Ngada berorientasi model pembelajaran kooperatif tipe Jigsaw.

Produk yang dikembangkan berupa desain pembelajaran tematik berorientasi pembelajaran kooperatif tipe Jigsaw ini kemudian akan divalidasi oleh tim ahli atau validator yang telah dipilih dan bersedia melakukan kegiatan validasi atas produk yang dikembangkan. Kegiatan validasi pada desain pembelajaran tematik ini dilakukan oleh 2 orang dosen yaitu Bapak Dr. Aan Nurfahrudianto, M.Pd dan Pelipus Wungo Kaka, M.Pd dan 1 orang ahli materi guru SD kelas IV yaitu Ibu Hilda Yuliana Tawa, S.Pd.

f) Mengembangkan Strategi Pembelajaran:

Pada tahap ini peneliti menentukan strategi dalam mendesain perangkat pembelajaran yang hendak digunakan guna mencapai tujuan yang diharapkan. Bentuk strategi yang digunakan dalam desain perangkat pembelajarn tematik berorientasi model pembelajaran kooperatif tipe Jigsawberbantuan lembar kerja siswa budaya lokal Ngada adalah Direct Instruction (model pembelajaran langsung) dalam kegiatan pembelajaran untuk mengimplementasikan aktivitas pembelajaran yaitu aktivitas pra-pembelajaran atau kegiatan pembuka, penyajian materi pembelajaran atau kegiatan inti dan aktivitas penutup atau yang biasa disebut kegiatan penutup. 
Strategi pembelajaran yang digunakan adalah pembelajaran dengan menggunakan model pembelajaran kooperatif tipe Jigsaw. Aktivitas atau kegiatan pembuka dilakukan untuk mengenalkan siswa dengan materi atau bahan yang akan dipelajari. Penyajian materi sendiri atau untuk kegiatan intinya dilakukan dengan menjelaskan secara garis besar apa yang hendak di pelajari kepada peserta didik dengan kata-kata atau kalimat yang tentunya mudah di pahami dan dimengerti oleh peserta didik. Kegiatan penutup. Dalam kegiatan penutup ini pendidik mengulang kembali secara garis besar apa yang telah peserta didik yang dalam hal ini merupakan anak usia dini pelajari. Pengulangan ini bertujuan untuk menanamkan kedalam memori anak tentang apa yang telah dipelajari. Sehingga anak tidak mudah lupa dengan apa yang dipelajari. Setelah itu barulah pendidik menarik kesimpulan tentang sudah sejauh mana tingkat pemahaman peserta didik berkaitan dengan kemampuan anak. Secara umum strategi pembelajaran dalam desain perangkat pembelajaran ini dikembangkan dengan mengikuti alur atau sintaksis dari pembelajaraan kooperatif tipe Jigsaw.

g) Tahap Mengembangkan Bahan Ajar/Mengembangkan dan Memilih Materi Instruksional:

Tahap mengembangkan bahan ajar dalam menyusun desain pembelajaran berupa rencana pelaksnaan pembelajaran (RPP) ini, diawali dengan menentukan hal-hal pokok yang diperlukan rencana pelaksanaan pembelajaran (RPP) setiap kompetensi dasar pada setiap sub tema dan pembelajaran, materi pokok yang berfungsi memberi makna terhadap kompetensi, indikator pencapaian, langkah-langkah pembelajaran, penilaian dalam pembelajaran dan mengumpulkan bahan acuan yang dimanfaatkan dalam pengembangan desain pembelajaran. Peneliti juga menggunakan LKS berbasis budaya lokal Ngada sebagai referensi yang akan dgunakan dalam menyusun desain pembelajaran tematik ini. Proses yang dilakukan dalam tahapan mengembangkan bahan ajar adalah sebagai berikut.

1) Menyusun Draf Desain Pembelajaran Tematik: Langkah pertama dalam tahapan ini adalah menyusun draf desain pembelajaran tematik. Desain pembelajaran disusun berbantuan lembar kerja siswa budaya lokal Ngada pada tema indahnya keberagaman di negeriku yang telah disediakan oleh Oliva Bolo. Desain pembelajaran tematik pada tema indahnya keberagaman di Negeriku yang dikembangkan ini, terdiri atas tiga sub tema. Masing-masing sub tema terdiri atas enam pembelajaran. Desain pembelajaran yang disusun ini adalah sesuai dengan keadaan di sekitar lingkungan masyarakat Ngada.

2) Mendesain Cover: Cover merupakan tampilan awal dari desain pembelajaran tematik berbasis pembelajaran kooperatif tipe Jigsaw dengan suplemen lembar kerja siswa berbasis budaya lokal yang dikembangkan, baik tampilan awal maupun tampilan akhir. Tampilan cover dapat dilihat pada gambar berikut ini.
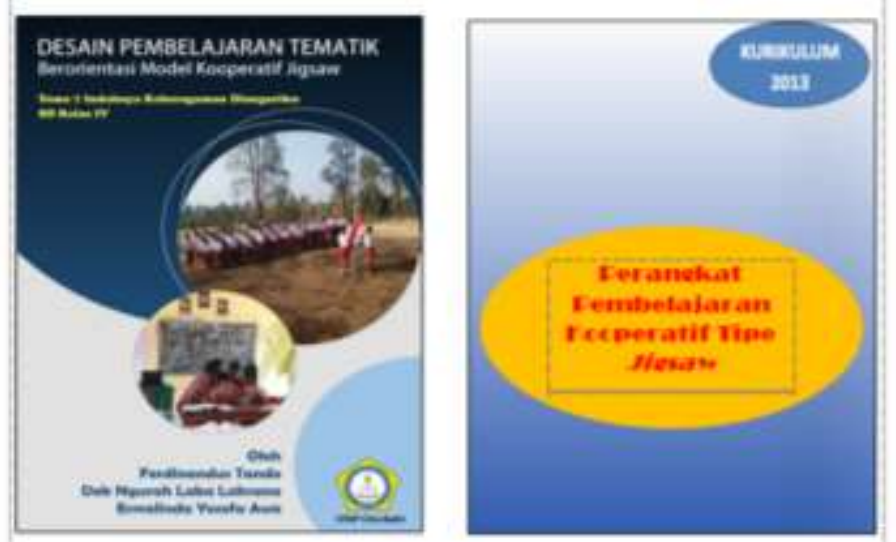

Gambar 1. Tampilan Sampul Depan

3) Kata Pengantar: Pada kata pengantar penulis mengucap syukur kepada Tuhan yang Maha Esa karena atas berkat dan perlindungannya sehingga penulis dapat menyelesaikan pengembangan desain pembelajaran tematik ini dengan baik.

4) Daftar Isi: Pada daftar isi, memuat penomoran dari sub-sub atau komponen dalam produk yang dikembangkan antara lain halaman judul, kata pengantar, daftar isi, rencana pelaksanaan pembelajaran (RPP) dari setiap sub tema dan lembar kerja siswa dari setiap sub tema.

5) Pendahuluan: Pada pendahuluan sesuatu yang akan dibahas adalah latar belakang mengaapa perlu adanya suatu desain pembelajaran yang berupa Rencana Pelaksanaan Pembelajara (RPP). Hal yang mendasar pada pembahasan yang terdapat pada pendahuluan adalah sesuatu kendala-kendala yang berkaitan dengan penggunaan Rencana Pelaksaanan Pembelajaran (RPP) yang terjadi pada guru-guru yang sedang mengajar, dan tidak menggunakan sesuatu yang yang bersifat budaya lokal Ngada. 
6) Isi Produk: Isi produk adalah rencana pelaksanaan pembelajaran (RPP) yang disajikan atau dibuat oleh peneliti dengan mengkaitkan LKS budaya lokal Ngada pada tema Indahnya keberagaman di Negeriku untuk siswa kelas IV SD yang terdiri dari 3 sub tema dan dari masing masing sub tema terdiri atas 6 pembelajaran serta dibuat dengan menggunakan langkah-langkah model pembelajaran kooperatif tipe jigsaw.

\section{Hasil Pengujian Produk \\ Pengujian Oleh Ahli Konten/materi}

Secara keseluruhan hasil validasi desain pembelajaran tematik oleh ahli materi mendapatkan skor 34 dengan rata-rata 97,57, berdasarkan kriteria kelayakan produk, skor tersebut termasuk ke dalam kategori sangat valid dan dinyatakan layak untuk diujicobakan.

Pengujian oleh ahli bahasa: Hasil validasi ahli bahasa mendapatkan skor 42 dengan rata-rata 93,33, berdasarkan kriteria kelayakan produk, skor tersebut termasuk dalam kriteria sangat layak.

Pengujian Oleh Ahli Desain: Hasil validasi ahli mendapatkan skor 45 dan rata rata skor yang diperoleh 81,82, berdasarkan kriteria kelayakan produk, maka skor termasuk dalam kategori layak.

\section{Revisi Produk}

Pada tahap ini, setelah dilakukan penilaian pada lembar kuisioner yang dilakukan oleh validator maka didapatkan hasil penilain antara lain sebagai berikut. 1) penilain yang dilakukan oleh ahli materi memperoleh rata-rata 95,57 berada dalam kriteria sangat layak. 2) penilaian yang dilakukan oleh ahli bahasa memperoleh rata-rata 93,33 berada dalam kriteria sangat layak. 3) penilaian yang dilakukan oleh ahli desain memperoleh rata-rata 81,82 berada pada kriteria layak. Setelah dilakukan penilaian, peneliti melakukan kembalirevisi untuk ahli desain sedangkan untuk ahli konten dan ahli bahasa tidak dilakukan lagi revisi. Secara garis besar hasil validasi produk pengembangan desain pembelajaran dapat dilihat pada tabel berikut ini.

Tabel 1. Hasil Validasi Desain Pembelajaran

\begin{tabular}{|c|c|c|c|}
\hline Ahli & Skor & Rata-rata & Kategori \\
\hline Materi & 34 & 97,57 & Sangat layak \\
\hline Bahasa & 42 & 93,33 & Sangat layak \\
\hline Desain & 45 & 81,82 & Layak \\
\hline
\end{tabular}

\section{Keunggulan Produk Desain}

Pengembangan desain pembelajaran tematik berorientasi model pembelajaran kooperatif tipe Jigsaw pada tema indahnya keberagaman di negeriku ini tersusun dalam dua bagian utama yaitu : (1) Rencana Pelaksanaan Pembelajaran, dan (2) Lembar kerja siswa berbasis budaya lokal Ngada. Berikut adalah penjelasan untuk masing-masing bagian yang terdapat dalam desain pembelajaran tematik pada tema indahnya keberagaman dinegeriku berbantuan lks budaya lokal ngada berorientasi model pembelajaran kooperatif tipe jigsaw yang telah dikembangkan:

a. Rencana Pelaksanaan Pembelajaran

Rencana pelaksanaan pembelajaran tematik ini dikembangkan berorientasi model pembelajaran kooperatif tipe Jigsaw pada tema indahnya keberagaman di negeriku. Perangkat pembelajaran yang dikembangkan terdiri dari 3 sub tema pada tema 7 dan setiap sub tema terdiri dari 6 pembelajaran. Adapun komponen-komponen dalam rencana pelaksanaan pembelajaran tematik berorientasi model pembelajaran kooperatif tipe Jigsaw yang dikembangkan antara lain sebagai berikut.

1) Identitas

Komponen awal pada identitas rencana pelaksanaan pembelajaran terdiri dari: Satuan Pendidikan, Kelas/

Semester, Tema, Sub Tema 1, Pembelajaran, Alokasi Waktu, Tanggal pelaksanaan dan KBM:

2) Kompetensi Inti

Kompetensi inti terdiri dari empat item yang terdiri dari:

KI 1 : Menerima, menjalankan, dan menghargai ajaran agama yang dianutnya.

KI 2 : Menunjukkan perilaku jujur, disiplin, tanggung jawab, santun, peduli, percaya diri, dalam berinteraksi dengan keluarga, teman, guru dan tetangganya.

KI 3 : Memahami pengetahuan faktual, konseptual, prosedural, dan metakognitif pada tingkat dasar dengan cara mengamati, menanya, dan mencoba berdasarkan rasa ingin tahu tentang dirinya, makhluk ciptaan Tuhan dan kegiatannya, serta benda-benda yang dijumpainya di rumah, di sekolah, dan tempat bermain. 
KI 4 : Menyajikan pengetahuan faktual dalam bahasa yang jelas, sistematis dan logis, dalam karya yang estetis, dalam gerakan yang mencerminkan anak sehat, dan dalam tindakan yang mencerminkan perilaku anak beriman dan berakhlak mulia.

3) Kompetensi Dasar dan Indikator: Pada komponen ini terdiri dari kompetensi dasar dari beberapa mata pelajaran dan indikator pencapaian kompetensi yang dimuat berdasarkan kompetensi yang dimuat.

4) Tujuan Pembelajaran: Tujuan pembelajaran ini merupakan lanjutan dari indikator-indikator yang dimuat melalui pembelajaran kooperatif tipe jigsaw.

5) Kegiatan Kontekstual: Pada kegiatan kontekstual dimuat: 1) Nama Kegiatan, 2) Deskripsi Kegiatan. 3) Langkah-langkah Kegiatan.

6) Metode, Model dan Pendekatan: Metode, model dan pendekatan yang digunakan dalam perangkat pembelajaran yang dikembangkan adalah metode: ceramah, tanya jawab, diskusi, demonstrasi. Model: kooperatif tipe Jigsaw dan menggunakan pendekatan: tematik integrative.

7) Alat, Media dan Sumber Belajar: Alat, media dan sumber belajar disesuaikan dengan materi dari setiap sub tema pada masing-masing pembelajaran.

8) Kunci Kreatif: Kunci kreatif merupakan kode atau tepukan yang digunakan dalam kegiatan pembelajaran berlangsung, ketika guru menyemangati siswa dalam kegiatan belajar mengajar. Kunci kreatif dalam perangkat pembelajaran ini terdiri dari tepuk salut dan tepuk semangat.

9) Alur Kegiatan: Alur kegiatan pada perangkat pembelajaran tematik berbasis pembelajaran kooperatif tipe jigsaw terdiri dari tiga jenis kegiatan yakni: kegiatan pendahuluan, kegiatan inti, kegiatan penutup. Setiap kegiatan disertai dengan deskripsi kegiatan dan alokasi waktu.

10) Penilaian: Penilaian terdiri dari penilaian sikap spiritual yang dilengkapi dengan pedoman observasi sikap spiritual, penilaian sikap sosial (disiplin), pnilaian pengetahuna yang dilengkapi dengan kisi-kisi soal tes.

b. Lembar Kerja Siswa

Lembar kerja siswa berbasis budaya lokal Ngada ini telah dikembangkan oleh Oliva Bolo (peneliti terdahulu) yang disesuaikan dengan materi setiap pembelajaran. Keunggulan dari lembar kerja siswa ini adalam memiliki komponen-komponen dalam lembar kerja siswa berbantuan LKS budaya lokal Ngada yang dikembangkan antara lain sebagai berikut. 1) Identitas, 2) Nama kelompok, 3) Teks bacaan, 4) Analisis kegiatan, 5) Soal. Dalam pengembangan desain pembelajaran tematik berorientasi model pembelajaran kooperatif tipe Jigsaw pada tema indahnya keberagaman di negeriku berbantuan lembar kerja siswa budaya lokal Ngada, digunakan lembar kerja siswa berbantuan lks budaya lokal Ngada untuk mempermudah siswa dalam mempelajari materi karena materi yang terdapat di dalam lembar kerja siswa ini adalah materi yang berbantuan LKS budaya lokal artinya lembar kerja siswa tersebut bersifat kontekstual, sehingga dapat mempermudah siswa dalam menjawab soal-soal yang terdapat dalam lembar kerja siswa yang dimuat dalam perangkat pembelajaran tematik yang dikembangkan oleh peneliti.

Produk desain pembelajaran ini mempunyai keunggulan yaitu rencana pelaksanaan pembelajaran (RPP) yang peneliti kembangkan memang sudah sesuai dengan kebiasaan budaya lokal masyarakat Ngada. selain itu peneliti juga merasa bangga dengan model pembelajaran yang dikembangkan adalah model pembelajaran kooperatif tipe Jigsaw karena belum semua sekolah di Kabupaten Ngada ini menggunakan pembelajaran seperti yang peneliti kembangkan.

Pengembangan desain pembelajaran tematik pada tema indahnya keberagaman dinegeriku berbantuan lks budaya lokal ngada berorientasi model pembelajaran kooperatif tipe Jigsaw memberikan kontribusi positif untuk meningkatkan literasi siswa berbasis kompetensi. Integrasi nilai budaya lokal dalam pengembangan kurikulum seperti membuat tujuan belajar, merancang bahan belajar, menentukan strategi pembelajaran, media belajar, dan evaluasi pembelajaran adalah penting dilakukan untuk kualitas pembelajaran.

\section{Pembahasan}

Produk desain pembelajaran ini mempunyai keunggulan yaitu rencana pelaksanaan pembelajaran (RPP) yang peneliti kembangkan memang sudah sesuai dengan kebiasaan budaya lokal masyarakat Ngada. Selain itu peneliti juga merasa bangga dengan model pembelajaran yang dikembangkan adalah model pembelajaran kooperatif tipe Jigsaw karena belum semua sekolah di Kabupaten Ngada ini menggunakan pembelajaran seperti yang peneliti kembangkan.

Pengembangan desain pembelajaran yang dilakukan oleh peneliti adalah berupa desain pembelajaran tematik pada tema indahnya keberagaman di negeriku berbantuan LKS budaya lokal Ngada. Pengembangan desain pembelajaran ini telah memenuhi syarat kelayakan penggunaan produk karena memiliki derajat validasi dengan kualitas yang baik. Dari ahli materi dan ahli bahasa mendapatkan kriteria sangat layak, sedangkan dari ahli desain dengan kriteria layak. Jika minimal kriteria validasi yang dicapai adalah layak atau berada pada 
rentang 71\%-85\%, dan kriteria sangat layak berada pada rentang $86 \%-100 \%$. Berdasarkan hasil revisi dan analisis diatas dapat disimpulkan bahwa pengembangan desain pembelajaran tematik berbantuan LKS budaya lokal layak untuk digunakan. Kelayakan desain pembelajaran menggunakan LKS budaya lokal telah dilakukan pengembangan sebelumnya dan telah terbukti layak untuk digunakan (Pulu, Laksana, dan Wau, 2020; Seso, Laksana, dan Kaka, 2020).

Pembelajaran menggunakan pendekatan budaya terbukti efektif digunakan dalam pembelajaran. Stephens (2000) pembelajaran berbasis budaya berusaha mengintegrasikan sistem pengetahuan asli (lokal) dan pengetahuan Barat di sekitar topik-topik atau materi pelajaran dengan tujuan untuk meningkatkan pemahaman siswa terhadap konsep-konsep yang dipelajari dan sekaligus juga untuk meningkatkan pemahaman siswa terhadap budaya lokalnya. Lebih lanjut, Stephens (dalam Laksana dkk, 2015) mengatakan bahwa karakteristik pembelajaran berbasis budaya meliputi, (1) dimulai dengan topik tentang manfaat budaya dan melibatkan ahliahli budaya, (2) menghubungkan pembelajaran sains dengan topik-topik budaya dan standar sains, (3) menyediakan kesempatan yang luas kepada siswa untuk mengembangkan pemahaman secara mendalam tentang pengetahuan budaya yang berkaitan dengan sains, (4) menggabungkan praktek pembelajaran yang sesuai dengan konteks budaya, memfokuskan pada pemahaman siswa, dan menggunakan pengetahuan dan keterampilan, (5) melibatkan asesmen autentik yang membimbing pembelajaran dan menyediakan pemahaman sains dan budaya, pengembangan penalaran dan keterampilan yang berhubungan dengan standar.

\section{SIMPULAN DAN SARAN}

Adapun kesimpulan dari penelitian ini adalah 1) telah menghasilkan produk pembelajaran tematik pada tema indahnya keberagaman dinegeriku berbantuan LKS budaya lokal Ngada berorientasi model pembelajaran kooperatif tipe Jigsaw terdiri dari beberapa bagian diantaranya cover, kata pengantar, rencana pelaksanaan pembelajaran (RPP) tema 7 yang terdiri dari 3 sub tema dan masing-masing sub tema terdapat 6 pembelajaran, lembar kerja siswa berbantuan LKS budaya lokal Ngada, dan cover penutup. 2) Kualitas produk hasil pengembangan desain pembelajaran tematik pada tema indahnya keberagaman dinegeriku berbantuan LKS budaya lokal Ngada berorientasi model pembelajaran kooperatif tipe Jigsaw telah mencapai kategori layak. Berdasarkan data hasil uji coba produk akhir dari ahli konten atau materi, dengan rerata skor 97,57\%, ahli bahasa dengan rerata skor dengan 93,33\%, dan ahli desain dengan rerata skor $81,82 \%$, dengan demikian dapat disimpulkan bahwa hasil penilaian produk dari ke tiga ahli diatas berada pada kategori sangat layak untuk digunakan.

Dalam pengembangan ini terdapat beberapa saran mengenai pengembangan desain pembelajaran tematik pada tema indahnya keberagaman dinegeriku berbantuan LKS budaya lokal Ngada berorientasi model pembelajaran kooperatif tipe Jigsawadalah sebagai berikut. (1) perlu dilakukan pengembangan desain pembelajaran menggunakan model pembelajaran lainnya yang sesuai dengan karakteristik peserta didik dan mengkaji lebih dalam budaya lokal lainnya yang diintegrasikan dengan materi tematik yang disajikan dalam lembar kerja siswa berbantuan LKS budaya lokal Ngada, (2) Produk pengembangan berupa desain pembelajaran tematik pada tema indahnya keberagaman dinegeriku berbantuan LKS budaya lokal Ngada berorientasi model pembelajaran kooperatif tipe Jigsaw ini perlu dilakukan uji coba skala besar pada beberapa pengguna produk yakni guru.

\section{DAFTAR RUJUKAN}

[1] Ayu, P., \& Mawardi. 2017. Pengembangan Desain Pembelajaran Tematik Terpadu Berbasis Kebutuhan Belajar Siswa Kelas Tiga Sekolah Dasar. Jurnal Penelitian Tindakan dan Pendidikan, 3(2), 144-145.

[2] Fathurrohman, M. 2015. Model-model Pembelajaran Inovatif. Ar-ruzz Media. Yogyakarta.

[3] Hakim, I.N. 2014. Pembelajaran Tematik-Integratif di SD/MI dalam Kurikulum 2013. Insania, 19(1)

[4] Hamdayana, J. 2015. Model dan Metode Pembelajaran Kreatif dan Berkarakter. Bogor: Ghalia Indonesia.

[5] Huda, M. 2011. Cooperative Learning. Yogyakarta: Pustaka Pelajar.

[6] Ismail. 2008. Ilmu Pendidikan Teoritis. Jakarta: Ganeca.

[7] Laksana, D.N L. \& Lawe, F. 2015. Penggunaan Media Berbasis Budaya Lokal dalam Pembelajaran IPA untuk Meningkatkan Aktivitas dan Pemahaman Konsep IPA Siswa Sekolah Dasar. Jurnal Ilmiah Pendidikan Citra Bakti, 2 (1), 27-37.

[8] Laksana, D.N.L. \& Rabu, K. 2015. Pembelajaran Kontekstual Bermuatan LKS Dalam Upaya Meningkatkan Pemahaman Konsep IPA dan Aktivitas Belajar Siswa SD. Jurnal Ilmiah Pendidikan Citra Bakti, 2(1), 78-89. 
[9] Laksana, D.N.L. Lawe, Y.U., Ripo, F., Bolo, M.O., \& Dua, T.D. 2020. Lembar Kerja Siswa Berbasis Budaya Lokal Ngada Untuk Pembelajaran Tematik Siswa Sekolah Dasar. Jurnal Pendidikan Dasar Nusantara, 5(2), 136-137

[10] Permendikbud Republik Indonesia Nomor 65. 2013. Tentang Standar Proses Pendidikan Dasar Dan Menengah.

[11] Pulu, D., Laksana, D.N.L., \& Wau, M.P. 2020. Desain Pembelajaran Tematik Berbantuan LKS Budaya Lokal Berorientasi Model Pembelajaran Inkuiri untuk Siswa Sekolah Dasar. Jurnal Pendidikan dasar Flobamorata, 1(2), 60-72

[12] Seso, F., Laksana, D.N.L., \& Kaka, P.W. 2020. Pengembangan Desain Pembelajaran Tematik Tema Berbagai Pekerjaan Bermedia LKS Budaya Lokal Ngada Berorientasi Model Pembelajaran Berbasis Masalah untuk Siswa Kelas IV Sekolah Dasar di Kecamatan Inerie. Jurnal Citra Pendidikan, 1(1), 59-69

[13] Sumarno, Alim. 2012. Penelitian Kausalitas Komparatif. Surabaya: Elearning Unesa.

[14] Trianto. 2009. Mengembangkan Model Pembelajaran Tematik. Jakarta: PT. Prestasi Pustakaraya.

[15] Undang-Undang nomor 20 tahun 2003 tentang Sistem Pendidikan Nasional. 2003. Jakarta: Kementrian Pendidikan Nasional. 